\title{
NORTH BRETON ISLAND RESTORATION, DESIGNING TO INCREASE A BARRIER ISLAND'S HABITAT AND LONGEVITY
}

\author{
Murat Utku, P.E., Ph.D. O'Brien and Gere (OBG). murat.utku@obg.com \\ Gary B. Emmanuel, P.E., OBG, gary.emmanuel@obg.com \\ Michael Poff, P.E., Coastal Engineering Consultants, Inc., mpoff@cecifl.com
}

\section{INTRODUCTION}

The product and purpose of a well-planned program of investigation and design will be realized later this year when restoration construction begins on North Breton Island. North Breton Island is the southern-most of a chain of barrier islands forming the Chandeleur Islands. The barrier island formation lies within the Mississippi River delta plain system approximately 62 miles southeast from the metropolitan city of New Orleans, LA (Figure 1). Under the authority of the Natural Resource Damage Assessment (NRDA) process, NRDA Trustees selected enhancement of North Breton Island as part of the 2014 Deepwater Horizon NRDA Phase III Early Restoration Plan to help restore injuries to natural resources (Trustees, 2014). The U.S. Fish and Wildlife Service (USFWS) is the lead implementing agency for this Project. The Project includes restoring the barrier shoreline along the entire length of North Breton Island through beach, dune, and marsh fill placement utilizing an offshore sand source in the Borrow Area located approximately 3.3 nautical miles (NM) east of the Restoration Area in the Gulf of Mexico.

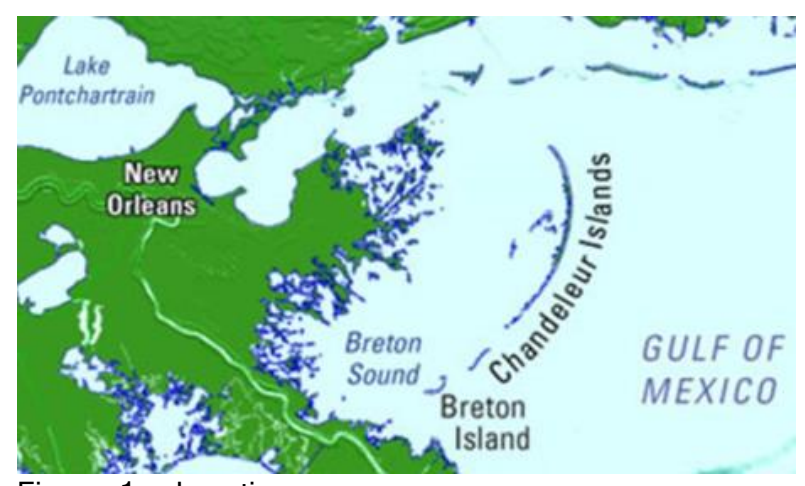

Figure 1 - Location

The purpose of the Project is to increase island longevity by restoring North Breton Island's geomorphologic and ecologic form and function (GEFF), providing wetland habitat for a diverse number of plant and animal species including brown pelicans, terns, skimmers, and gulls subjected to the effects of the Deepwater Horizon Oil Spill of 2010. Under the USFWS's oversight, a project team consisting of federal agencies and private consultants has carried out a thorough Statement of Work involving Data Collection, Alternatives Development and Evaluation, Preliminary Design, Permitting, and Final Design. With these phases complete, the project is ready for the construction phase. This paper will discuss the design development and evaluation process for the restoration of an entire island.

\section{EVALUATION OF ALTERNAITIVES}

A detailed alternatives evaluation was conducted as part of the plan formulation for the Project. Restoring the island's ecologic form and function to sustain wetland habitat on a barrier island requires enlarging the existing island footprint, both in width and elevation, and by raising the beach and dune to minimize breaching during the design life. The project team conducted a detailed modeling process to assess island longevity in the face of the destructive processes of the island's Gulf environment. The selected design template was subjected to barrier island evolutionary geomorphic processes including gulfside erosion, bayside erosion, subsidence, and sealevel rise over a 15-year design life, broken into segments surrounding three tropical storms. Impacts of tropical storms on the proposed restoration template were simulated by USGS using the process-based model XBeach (Figure 2).

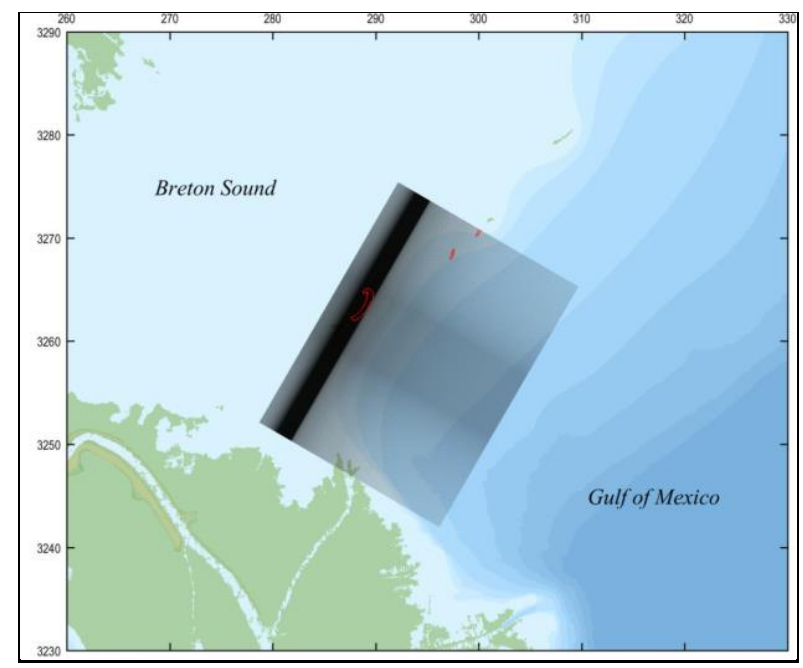

Figure 2 - X Beach model grid

The North Breton Island restoration design template showed resilience during the modeled 15-yr design life and has formed the basis for state and federal permits and completed construction drawings and specifications. Construction is planned to begin in late 2018. Figures 3 and 4 present the plan view and a cross section of the design.

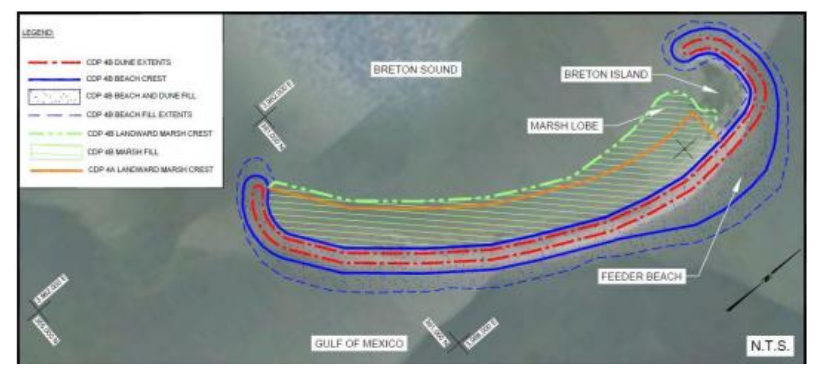

Figure 3 - Plan view

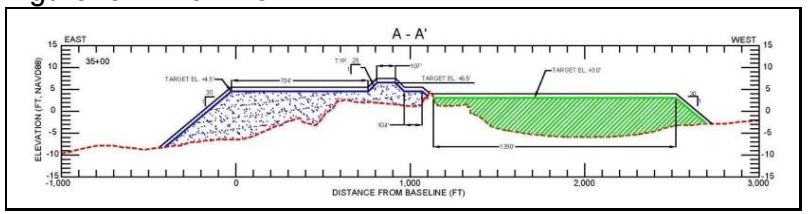

Figure 4 - Section view 